\title{
International Implications of Labeling Foods Containing Engineered Nanomaterials
}

\author{
Grieger, Khara D.; Hansen, Steffen Foss; Mortensen, Ninell P.; Cates, Sheryl; Kowalcyk, Barbara
}

Published in:

Journal of Food Protection

Link to article, DOI:

10.4315/0362-028X.JFP-15-335

Publication date:

2016

Document Version

Peer reviewed version

Link back to DTU Orbit

Citation (APA):

Grieger, K. D., Hansen, S. F., Mortensen, N. P., Cates, S., \& Kowalcyk, B. (2016). International Implications of Labeling Foods Containing Engineered Nanomaterials. Journal of Food Protection, 79(5), 830-842.

https://doi.org/10.4315/0362-028X.JFP-15-335

\section{General rights}

Copyright and moral rights for the publications made accessible in the public portal are retained by the authors and/or other copyright owners and it is a condition of accessing publications that users recognise and abide by the legal requirements associated with these rights.

- Users may download and print one copy of any publication from the public portal for the purpose of private study or research.

- You may not further distribute the material or use it for any profit-making activity or commercial gain

- You may freely distribute the URL identifying the publication in the public portal 
This is a post-print version of Grieger et al. (2016). International Implications of Labeling Foods Containing Engineered Nanomaterials. Journal of Food Protection, 79(5), 830-842.

The printed versio of the paper is available at: doi: 10.4315/0362-028X.JFP-15-335

International Implications of Labeling Foods containing Engineered Nanomaterials

Khara D. Grieger $^{1 *}$, Steffen Foss Hansen ${ }^{2}$, Ninell P. Mortensen ${ }^{1}$, Sheryl Cates ${ }^{1}$, Barbara

Kowalcyk $^{1}$

${ }^{1}$ RTI International, 3040 E. Cornwallis Dr., Research Triangle Park, NC, USA 27609

${ }^{2}$ DTU Environment, Technical University of Denmark, Kongens Lyngby, Denmark 2800

Keywords: Engineered nanomaterials; food, labeling; stakeholders

*Author for correspondence. Tel: (919) 541-7243; Fax: (919) 541-7155

E-mail: kgrieger@rti.org 
This is a post-print version of Grieger et al. (2016). International Implications of Labeling Foods Containing Engineered Nanomaterials. Journal of Food Protection, 79(5), 830-842.

The printed versio of the paper is available at: doi: 10.4315/0362-028X.JFP-15-335

\section{ABSTRACT}

To provide greater transparency and comprehensive information to consumers regarding their purchase choices, the European Parliament and Council have mandated that foods containing engineered nanomaterials (ENMs) be labelled, via Regulation No. 1169/2011. This paper reviews the main concerns related to the use of ENMs in foods and discusses the potential impacts of labeling foods containing ENMs on diverse stakeholder groups, including those residing in non-European countries including the United States (US). We also provide recommendations to stakeholders to overcome existing challenges related to labeling foods containing ENMs. We find that the revised European food labeling requirements will likely result in a number of positive developments as well as a number of challenges for stakeholders in both European and non-EU countries. While labeling foods containing ENMs will likely improve transparency and information to facilitate consumer decisions, also potentially building trust among food safety authorities and consumers, there are a number of critical obstacles to overcome prior to the successful implementation of these labeling requirements. These include the need for i) harmonized information requirements or regulations between countries residing in different regions of the world, ii) clarification on the regulatory definitions of ENMs to be used for food labeling, iii) robust techniques to detect, measure, and characterize diverse ENMs in food matrices, and iv) clarification on the list of ENMs that may be exempt from labeling requirements such as several food additives used for decades. It is recommended that food industries and food safety authorities be more proactive in communicating to the public and consumer groups regarding the potential benefits and risks of using ENMs in foods. It is also recommended that efforts are made to improve harmonization of information requirements between countries to avoid potential international trade barriers. 
This is a post-print version of Grieger et al. (2016). International Implications of Labeling Foods Containing Engineered Nanomaterials. Journal of Food Protection, 79(5), 830-842.

The printed versio of the paper is available at: doi: 10.4315/0362-028X.JFP-15-335

\section{INTRODUCTION}

In the past decade, there has been an increase in the number of consumer products available which contain engineered nanomaterials (ENMs) ${ }^{1}$, including those within agriculture and food sectors $(3,27,71)$. The use of ENMs in foods raises not only a number of scientific and regulatory challenges in terms of assessing their safety but also presents a number of ethical, social, and legal concerns. This is due to the extensive uncertainties related to characterizing the potential environmental, health, and safety risks of ENMs (49) and the fact that many ENMs exhibit unique functional properties related to their nano-scale sizes and may behave differently than bulk-scale materials $(4,11,76)$. There are also a number of other issues including analytical challenges to detecting ENMs in complex matrices, questions on how to regulate ENMs in food $(37,50)$, and ethical and social concerns including issues of trust between consumer groups, industry, and food safety authorities.

Thus far, there have been various responses from stakeholder groups on how to handle the presence of ENMs in food. Some consumer groups have called for a moratorium on the production and sale of products containing ENMs (46) or agricultural practices involving ENMs

\footnotetext{
${ }^{1}$ While there are varying definitions of the term "engineered nanomaterial" among regulatory agencies and international organizations (e.g. 52), the European Commission (EC) has defined a "nanomaterial" as particles in an unbound or as aggregate or agglomerate with greater than $50 \%$ of particles with an external dimension 1-100nm, regardless of origin (EC No 2011/696/EU) (16). EU Regulation on food information for consumers (EC No 1169/2011) provides a different definition of an ENM stating that "engineered nanomaterial means any intentionally produced material that has one or more dimensions of the order of $100 \mathrm{~nm}$ or less or that is composed of discrete functional parts, either internally or at the surface, many of which have one or more dimensions of the order of $100 \mathrm{~nm}$ or less, including structures, agglomerates or aggregates, which may have a size above the order of $100 \mathrm{~nm}$ but retain properties that are characteristic of the nanoscale. Properties that are characteristic of the nanoscale include: (i) those related to the large specific surface area of the materials considered; and/or (ii) specific physico-chemical properties that are different from those of the non-nanoform of the same material."
} 
This is a post-print version of Grieger et al. (2016). International Implications of Labeling Foods Containing Engineered Nanomaterials. Journal of Food Protection, 79(5), 830-842.

The printed versio of the paper is available at: doi: 10.4315/0362-028X.JFP-15-335

(92). The Members of the European Parliament (MEP) recently called for a moratorium on nanofoods based on the precautionary principle, citing that foods that contain ENMs should not be authorized until approved by the European Food Safety Authority (EFSA) (36). The US Department of Agriculture (USDA) also recently issued a policy memorandum clarifying the use of nanotechnology and ENMs in organic food production and handling, stating that ENMs are not allowed in organic production and handling unless a number of provisions are made (103). In response, the European Parliament and the Council revised Europe’s food labeling requirements (EU Regulation 1169/2011) to provide comprehensive information to consumers regarding their purchase choices. Part of these requirements mandate that foods containing ENMs are labelled, as denoted by 'nano' preceding the name of the ingredient in the list of ingredients (20, 21, 22, 35). These changes were effective as of December 2014. While these requirements are restricted to foods sold within the EU, it is likely to have consequences in nonEU countries including the United States (US). This paper first reviews the main concerns related to ENMs in food and then highlights and discusses the potential impacts of labelling foods containing ENMs on diverse stakeholder groups. Finally, recommendations are provided to help ensure the responsible development and use ENMs in foods, especially since this is often an overarching goal of nanotechnology strategic development $(48,75)$. This paper focuses on ENMs in foods, food supplements, and food additives which are intended for direct consumption rather than food packaging, ENM/nanotech-enabled food safety detection equipment, or the use of ENMs as biocides or pesticides. As emerging technologies will continue to be developed ahead of full scientific knowledge and within changing regulatory landscapes, this paper will help guide informed decisions on a potentially complex and controversial topic for diverse stakeholders. 
This is a post-print version of Grieger et al. (2016). International Implications of Labeling Foods Containing Engineered Nanomaterials. Journal of Food Protection, 79(5), 830-842.

The printed versio of the paper is available at: doi: 10.4315/0362-028X.JFP-15-335

This analysis is primarily based on a comprehensive literature review of ENMs in foods, including aspects of toxicology, safety, risk, regulation, food labeling, public perception, and consumer behavior. Numerous peer reviewed scientific journal articles, reports from regulatory agencies, reports from non-governmental organizations, as well as additional publically available literature such as news releases and conference proceedings were reviewed. In addition, the authors' own experience and background within fields of ENM risk, safety, toxicology, food policy and research, and regulation were also employed.

\section{THE USE OF ENGINEERED NANOMATERIALS (ENMS) IN FOODS}

Because ENMs often display novel properties and functionalities compared to their bulk scale counterparts, e.g. increased reactivity, optical, electrical properties (101), there has been increased interest in using these novel materials in a range of consumer products and applications including the food sector $(3,8,27,66,67,71,88,96)$. It was estimated in 2008 that more than 200 companies were involved in research and development efforts of foods containing ENMs, across the fields of agriculture, dietary supplements, engineering, processing, and packaging (8). Some have also estimated that $40 \%$ of all businesses within the food industry will be using nanotechnology by the end of 2015, including many large international food companies (46). To date, ENMs are used in food in four main categories: i) processing or production of foodstuffs to form nanostructured materials, ii) nano-sized encapsulations or engineered nanosized additives, iii) ENMs in food packaging such as in plastic polymers, and iv) ENM or nanotechnology-based applications for food safety and traceability $(8,9,67)$. ENMs are also used in agricultural production and animal feeds, including feed additives, veterinary drugs, biocides, and fertilizers (27). In terms of the use of ENMs in food processing, ENMs have been used to improve taste, color, flavor, texture, consistency, and bioavailability of nutrients such as 
This is a post-print version of Grieger et al. (2016). International Implications of Labeling Foods Containing Engineered Nanomaterials. Journal of Food Protection, 79(5), 830-842.

The printed versio of the paper is available at: doi: 10.4315/0362-028X.JFP-15-335

the use of nano-emulsions or nutraceuticals to enhance taste or improve nutritional content. Various nano-scale food additives are also used to help improve the stability of the food, improve a certain food property, or to increase bioavailability or potency of nutrients (27). In food packaging and food safety applications, ENMs have been used to improve or strengthen food packaging (i.e., extend shelf life and/or be more protective) and improve food safety practices such as employment in contamination detection methods $(8,67)$.

The main types of ENMs used in foods are inorganic, organic, and surface functionalized materials (4). The use of inorganic ENMs include metals and metal oxides (e.g. silver, titanium dioxide, zinc oxide, gold, iron) as well as non-metals (e.g. selenium, silicates) $(28,67)$. The use of organic ENMs include nano-clays, often used as used in diffusion barriers used to improve the “air tightness” of food packaging (67), nano-encapsulates which includes micelles, nanocapsules, nanocarriers and nanoemulsions, and other types of ENMs such as cellulose and chitosan (27). According to a number of analyses there are several hundred food products currently available or soon to be available to consumers which contain ENMs, which have been approved by food safety authorities even though their nano-scale dimensions may not always be well-accounted for or robustly considered in the approval process(es). A recent review of nanotechnology applications in food sectors reported 633 separate nanotechnology applications currently in use or expected in the near future using 55 different types of ENMs (27). This included 153 food additives, 51 unspecified food ingredients, 45 supplements, 5 novel foods, 1 enzyme, and 1 flavoring. Across these applications, the following types of ENMs were used: i) food additives consisting of nano-scale titanium dioxide, silica, zinc oxide, silver, nano-encapsulates, nanocomposites, chitosan, and niacin; ii) food ingredients consisting of nano-scale silica and nanoencapsulates; iii) supplements consisting of nano-scale iron, silver, gold, nano-composites, and 
This is a post-print version of Grieger et al. (2016). International Implications of Labeling Foods Containing Engineered Nanomaterials. Journal of Food Protection, 79(5), 830-842.

The printed versio of the paper is available at: doi: 10.4315/0362-028X.JFP-15-335

nano-encapsulates; iv) novel foods consisting of nano-encapsulates; v) enzymes consisting of nano-encapsulates; and vi) flavorings consisting of unspecified ENMs. These findings are similar to other analyses, which found approximately 200 food and beverage products containing ENMs in 2013 (46, 80). Interestingly, a recent inventory of ENMs used in agricultural, food, and feed sectors reported that there may be a transition in foods away from metal based ENMs towards the use of organic ENMs including nano-encapsulates and nano-composites (27). Table 1 provides a selected list of ENMs currently available or soon to be on the market in foods.

[Insert Table 1 here]

The exact concentrations of ENMs used in foods is largely unknown, mainly due to the lack of reporting requirements and challenges related to detecting and verifying ENMs in foods (e.g. 93, $96,101)$. One estimate suggests that dietary consumption of ENMs in foods within developed countries could be greater than $10^{12}$ particles/day, composed of both nano- and micro-sized particles and consisting mostly of titanium dioxide and mixed silicates (5). Another study investigating concentrations of titanium dioxide in various food products found concentrations up to $100 \mathrm{mg} \mathrm{TiO}_{2} /$ serving for powdered doughnuts and reported the greatest consumption among children 3.5-4.5 years old, followed by toddlers (2.5-3.5 yrs old) and younger toddlers (1.5-2.5 yrs old) and children 4-5 years old (107).

There are no established nano-specific exposure limits for ENMs in food neither in the EU, the US, nor elsewhere in the world, although limits on the bulk scale material do exist and used. This includes the EU's maximum limit of $50 \mu \mathrm{g}$ silver (Ag+) / kg food matrices (24) and FDA's limit of $17 \mu$ g silver (Ag+) in bottled water (39). Moreover, the use of titanium dioxide as a color additive (E171) is allowed without a restricted maximum level at this time (31). While there are a few respiratory exposure limits set on some ENMs, e.g. exposure limits for nanoscale titanium 
This is a post-print version of Grieger et al. (2016). International Implications of Labeling Foods Containing Engineered Nanomaterials. Journal of Food Protection, 79(5), 830-842.

The printed versio of the paper is available at: doi: 10.4315/0362-028X.JFP-15-335

dioxide, carbon nanotubes, and nano-silver $(74,86)$, there are no exposure limits related to oral exposures of ENMs through food applications specifically.

\section{SAFETY OF ENMS IN FOOD}

As described in a number of peer-reviewed papers and reports (e.g. 3, 9, 27), there are potential safety concerns regarding the use of ENMs in food applications. Although these data are still being gathered and evaluated, there are some suggestions that dietary exposure to ENMs may result in adverse health outcomes. Figure 1 provides an overview of the main processes involved in the fate and transformation of ENMs following oral exposure through tissue distribution and excretion of ENMs along with potential adverse health impacts resulting from consuming foods containing ENMs at these pathway stages. As illustrated in Figure 1, ENMs tend to interact with their surrounding matrix, including food matrices, gastrointestinal (GI) fluids, microbiota, blood, and other biological fluids. Due to these interactions, the characterization and assessment of adverse health impacts of digested ENMs is a challenging task. The physico-chemical properties of both ENMs and biological fluid influences other ENM interactions and behavior, including aggregation/agglomeration kinetics and the formation of a dynamic protein corona, which may depend on ENM properties such as nanoparticle size, surface charge, surface chemistry, and hydrophobicity $(6,64,72)$. These properties of ENMs are likely to change throughout the different stages following oral exposure of the ENM-food application, from digestion to tissue and organ distribution and excretion.

\section{[Insert Figure 1 here]}

Among other potential health effects, several ENMs used in food applications (e.g. silver, titanium dioxide) have been shown to have antimicrobial properties which could impact microbiome communities in the gut (e.g. 10,58). These changes may result in significant health 
This is a post-print version of Grieger et al. (2016). International Implications of Labeling Foods Containing Engineered Nanomaterials. Journal of Food Protection, 79(5), 830-842.

The printed versio of the paper is available at: doi: 10.4315/0362-028X.JFP-15-335

impacts, including impacts on critical functions including drug metabolism (83), nutrient uptake (58), colon function (2), behavior (70), and immune responses (95). Other impacts include responses to inflammatory bowel diseases (13), infectious diseases (99), and obesity (12). High levels of dietary uptake of ENMs have also been associated with compromised GI functioning such as Crohn's disease (63), inflammatory bowel disease (IBD) (79), autoimmune diseases and disorders (61), as well as cancer and immunomodulatory effects (1). Based on in vivo tests, ENMs have been shown to penetrate protective barriers within the body including the GI tract, become distributed in the body, and accumulate in different organs such as the lungs, liver, spleen, kidneys, etc. $(60,78)$. In in vivo studies, a range of adverse health effects have been documented including impacts on the pulmonary (97), cardiovascular (100), reproductive (55), and renal systems (45). Furthermore, other studies have shown that some ENMs may be capable of crossing blood-barriers $(59,60)$, and transfer ENMs to fetuses and offspring from exposed mothers via the placenta or milk (91).

Similar to other consumer products, there are a number of significant challenges to completing risk assessments for ENMs in food. Some of the main challenges relate to the ability to accurately detect and characterize ENMs in complex food matrices which may also contain natural (non-engineered) nanoscale materials, to develop proper sampling preparation techniques, to estimate accurate intake concentrations, to increase analytical sensitivity to determine concentrations of smaller ENMs (especially those below approx. $30 \mathrm{~nm}$ ), and to develop harmonized and validated methods throughout the risk assessment process (26, 28). Food safety authorities have produced guidance documents on how to approach risk assessments of ENMs in food $(23,40,41,43,44)$ which include guidance on ENM characterization and hazard testing; however these are primarily for guidance rather than regulatory purposes (27). 
This is a post-print version of Grieger et al. (2016). International Implications of Labeling Foods Containing Engineered Nanomaterials. Journal of Food Protection, 79(5), 830-842.

The printed versio of the paper is available at: doi: 10.4315/0362-028X.JFP-15-335

For these reasons, the assessments of ENMs in food are treated on a case-by-case basis (28). This has resulted in only a few ENMs being evaluated to date (28), although a number of food additives that may have nano-scale dimensions (e.g. calcium carbonate (E170), titanium dioxide (E171), iron oxide (E172), silicon dioxide (E551)) are currently undergoing safety evaluations by food safety authorities (27).

\section{ETHICAL, SOCIETAL, AND LEGAL CONCERNS}

In addition to the health and safety concerns, there are a number of ethical, societal, and legal concerns related to the application of nanotechnology and ENMs when it comes to food products, production, and applications. One of these is consumers' "right to know" for food products that contain ENMs. This is similar to previous and on-going debates and discussions regarding other novel foods, such as genetically-modified foods (e.g. 37, 84). European lawmakers have responded to this concern with the revised food labeling law EC No. 1169/2011, "on the provision of food information to consumers". In short, Regulation 1169/2011 modifies existing food labelling provisions in the EU to "allow consumers to make informed choices and to make safe use of food, while at the same time ensure the free movement of legally produced and marketed food” (19). Calls for similar labeling requirements have been made in other countries by consumer advocacy groups (46). Another ethical concern relates to the tendency of some consumer groups to associate food with the concept of "naturalness," whereby any deviation or change from the natural, original state of the food such as what may be caused by nanotechnologies or the use of ENMs may be perceived as "tampering with nature" (90). This is especially the case for European consumers. US consumers, on the other hand, tend to be more concerned that the use of nanotechnology may cause harm to people or exacerbate already- 
This is a post-print version of Grieger et al. (2016). International Implications of Labeling Foods Containing Engineered Nanomaterials. Journal of Food Protection, 79(5), 830-842.

The printed versio of the paper is available at: doi: 10.4315/0362-028X.JFP-15-335

existing social inequalities and conflicts (53), such as for instance inequalities between individuals promoting ENM-product use and those confronted with “downstream” risks.

One of the most important social concerns is consumers' low levels of trust in the industry and government with regard to handling ENMs in food. The public generally assumes that industry prioritizes profits over health and safety and governments are too weak or powerless to promote effective regulation (53). For instance one study found that, following concerns related to the risks and unintended uses of nanotechnologies, the second-greatest concern was the lack of trust in government regulation (65). Siegrist et al. (87) also noted that social trust was a critical factor in studies of public perception of nanotechnologies in food.

Thus far, the only legally binding regulation and labeling requirement established worldwide for the use of ENMs in food is European Regulation No. 1169/2011. No other countries or regulatory authorities have mandated food labeling requirements for ENMs in food. Despite the enactment of EU Regulation No. 1169/2011 “on the provision of food information to consumers," there are also serious concerns and challenges to the implementation, validation, and verification of this regulation. Many of these concerns are related to the ability to detect and verify that a food is composed of (or absent from) ENMS (e.g. 96). To date, there are currently no validated methods or reference standards to detect, identify, or quantify ENMs such as nanoparticles in complex food matrices $(26,96)$. Another main issue is the exact definition of an “engineered nanomaterial” which is relevant for foods. Currently, several different definitions have been proposed by regulatory agencies (e.g. EC No 2011/696/EU), international standards organizations such as the International Organization for Standardization (ISO) (52), as well as formulated as guidance by food safety authorities (e.g. 43, 44, 103). Some of these definitions, 
This is a post-print version of Grieger et al. (2016). International Implications of Labeling Foods Containing Engineered Nanomaterials. Journal of Food Protection, 79(5), 830-842.

The printed versio of the paper is available at: doi: 10.4315/0362-028X.JFP-15-335

but not all, have regulatory significance (e.g. EC No 2011/696/EU) while other definitions are intended for guidance to the food industry $(44,103)$. EU Regulation No. 1169/2011 which mandates foods containing ENMs are labelled also provides a separate definition of ENM (see footnote $^{1}$ ). Therefore, there are some legal concerns regarding these different definitions of ENMs relevant for food. Moreover, in terms of international impacts of labeling foods in the EU which contain ENMs, there also may be legal concerns regarding international litigations because non-EU countries, such as the US, do not have any nano-specific food regulations nor labeling requirements in place.

\section{FOOD LABELING LAWS IN EUROPE AND RELATED REGULATION FOR ENMS}

While numerous European regulations cover the use of ENMs in foods, the only food labeling law relevant for ENMs is EU Regulation No. 1169/2011. This revised regulation was enacted in October 2011 to facilitate informed consumer decision-making in Europe (35). Applicable as of December 13, 2014, this new EU regulation combines two separate Directives into one piece of legislation: 2000/13/EC on labeling, presentation and advertising of foodstuffs and 90/496/EEC on nutrition labeling for foodstuffs. Among other revisions for food labels (e.g., for improved information on allergens, refined oils/fats, meat and meat products), Regulation 1169/2011 mandates that foods containing ENMs be labelled in the list of ingredients by the term 'nano' next to the ENM (21). As detailed in Regulation 1169/2011, there are a number of ENMs that are not required to comply with these revised EU food labeling requirements: i) food additives and enzymes, due to the "carry-over principle" and serve no technological function in the finished product or used as processing aids; ii) carriers and substances which are not food additives and with the same purpose as carriers, used in quantities "strictly necessary;" and iii) substances used as processing aids which are not food additives still present in finished product, even in altered 
This is a post-print version of Grieger et al. (2016). International Implications of Labeling Foods Containing Engineered Nanomaterials. Journal of Food Protection, 79(5), 830-842.

The printed versio of the paper is available at: doi: 10.4315/0362-028X.JFP-15-335

form $(19,56)$. It should be noted that it is currently debated whether substances already present in the EU list of food additives (via EC Regulation 1129/2011) are exempt from these new labeling requirements (27).

EC regulation 1169/2011 also includes a different definition of ENMs compared to that proposed by EC No 2011/696/EU, specifying the inclusion of only intentionally produced ENMs in the nanoscale range ${ }^{1}$. It has been suggested by the EC’s Directorate-General for Health and Consumers (DG SANCO) that this definition be modified to include a threshold value (i.e. $\geq 50 \%$ of the total particle number are in the nano-scale, also supported by the EFSA Scientific Committee (25)), specify the exemption of food additives included by other regulations, and provide examples of ENMs which are likely to be included as ENMs in this regulation with one or more dimensions below $1 \mathrm{~nm}(15,57)$.

Apart from labeling requirements, ENMs are also covered by other forms of food regulation in the EU. The Novel Foods regulation (No. 258/97) defines novel foods as foods not significantly consumed in the EU before May 1997, and is intended to cover newly developed, innovative food, or those produced from new technologies or processes or those traditionally consumed outside the EU (32). A draft law related to the Novel Foods regulation was adopted in late 2013 and states that ENMs in foods covered in EU Regulation 1169/2011 have to be assessed and authorized under the Novel Foods requirements before being placed on the EU market $(18)^{2}$. It furthermore states that a novel food would also cover instances in which a new production process has been used or a food contains ENMs as covered by Regulation 1169/2011 (18). In

\footnotetext{
${ }^{2}$ After submission of this article, the European Commission announced publication of its final Novel Foods regulation (EU Regulation 2015/2283) in December 2015. This regulation states that foods containing ENMs are indeed considered as novel foods. This regulation also states that properties characteristic of ENMs include large specific surface area and other physico-chemical properties that may differ from the same substance at bulk scales, and the most up-to-date test methods should be used to assess the safety of these foods.
} 
This is a post-print version of Grieger et al. (2016). International Implications of Labeling Foods Containing Engineered Nanomaterials. Journal of Food Protection, 79(5), 830-842.

The printed versio of the paper is available at: doi: 10.4315/0362-028X.JFP-15-335

addition, the regulations on Food Additives (EU No. 1333/2008) and Food Supplements

(Directive 2002/46/EC) also cover substances added to food to improve their solubility or bioavailability $(33,34)$. Under these regulations, food additives, enzymes, flavorings, and supplements are required to undergo an assessment and authorization procedure before being placed on the market. Materials which are nano-forms of previously authorized food additives must be re-evaluated and authorized since they would be considered as new additives, as there are likely to be significant changes in production methods or starting materials used including changes in particle sizes $(28,56)$.

FOOD LABELING LAWS IN THE UNITED STATES AND RELATED REGULATION FOR ENMS

There are currently no labeling requirements for foods containing ENMs in the US. Similarly, there are no specific food safety regulations which specifically cover ENMs, although in theory ENMs are covered by existing rules and regulations to ensure a safe food supply. Foods are regulated in the US by the Food and Drug Administration (FDA) under the Federal Food, Drug, and Cosmetic Act of 1938 (21 U.S.C.) (38), which requires the safe and lawful use of food substances by manufacturers and end-users (43). Food additives, in addition to food substances, are covered under the Food Additives Amendment Act of 1958 and the Food and Drug Administration Modernization Act (FDAMA) of 1997 while color additives are covered by the Color Additive Amendment, both of which are amendments to the Federal Food, Drug, and Cosmetic Act (43).

FDA has published guidance documents to provide regulatory clarity for industry on the use of nanotechnology in FDA-regulated products (42). These guidance documents help industry 
This is a post-print version of Grieger et al. (2016). International Implications of Labeling Foods Containing Engineered Nanomaterials. Journal of Food Protection, 79(5), 830-842.

The printed versio of the paper is available at: doi: 10.4315/0362-028X.JFP-15-335

determine whether a product (or food substance) involves nanotechnology and provides guidance as to when industry should consider its regulatory status, safety, or public health impacts related to the use of nanotechnology (44). In one guidance document, FDA stated that they have not received any food or color additive petitions nor Generally Recognized As Safe (GRAS) affirmation petitions or notices for food substances with a size distribution at the nanoscale (43). They also stated that "at this time, we are not aware of any food substances intentionally engineered on the nanometer scale for which there are generally available safety data sufficient to serve as the foundation for the determination that the use of food substance is GRAS." Although regulatory definitions are not provided, FDA specifies that "nanotechnology products" are those "that contain or are manufactured using materials in the nanoscale range" or "contain or are manufactured using certain materials that otherwise exhibit related dimension-dependent properties or phenomena." FDA also specifies that the material or end product must be engineered in a "deliberate and purposeful” manner to have nano-scale dimensions or exhibit properties or phenomena attributable to nano-scale size, as opposed to nano-dimensions arising from naturally occurring or unintentional processes. Products are considered to involve nanotechnology if they include materials engineered with at least one external dimension between $1 \mathrm{~nm}$ and $100 \mathrm{~nm}$ as well as exhibit properties/phenomena attributed to nano-scale dimensions "even if these dimensions fall outside the nanoscale range, up to one micrometer (1,000 nm)." Similar to European food safety authorities, FDA evaluates products on a case-bycase basis.

FOOD LABELING LAWS IN OTHER COUNTRIES AND RELATED REGULATION FOR ENMS 
This is a post-print version of Grieger et al. (2016). International Implications of Labeling Foods Containing Engineered Nanomaterials. Journal of Food Protection, 79(5), 830-842.

The printed versio of the paper is available at: doi: 10.4315/0362-028X.JFP-15-335

Currently, there are no additional food labeling laws relevant for ENMs in other non-EU countries (27). While there are diverse measures to consider, cover, and/or provide guidance to industry in terms of handling ENMs, there has only been limited inclusion of ENM provisions in these existing pieces of legislation and none of them are legally binding (27).

\section{ADDITIONAL GUIDANCE FOR FOOD LABELING}

Before the implementation of the revised EU food labeling law (No 1169/2011), the ISO published a guidance document on the voluntary labelling of consumer products containing ENMs (51). This guidance document, which is not specific to foods but rather addresses all consumer products containing ENMs, describes some of the advantages of labeling products containing ENMs and provides recommendations for the content, placement, and instructions on label use (51). Similar to the rationale behind EU Regulation No. 1169/2011, the ISO guidance document suggests that the use of labels may improve openness and transparency and help consumers make informed decisions regarding products purchased and consumed. Labeling should also be done in a way that is clear, visible, legible, and portrays information that is truthful, substantiated, and not misleading (51).

\section{IMPACTS ON CONSUMERS}

One of the main objectives of revising EU's food labeling requirements is to increase transparency and improve consumers’ ability to make informed purchasing decisions. Thus, consumer perceptions and subsequent behavior - in the EU as well as other countries - following the implementation of the new EU food labels are likely to be one of the most critical outcomes of this revised regulation. In this way, the position of consumers in the marketplace is 
This is a post-print version of Grieger et al. (2016). International Implications of Labeling Foods Containing Engineered Nanomaterials. Journal of Food Protection, 79(5), 830-842.

The printed versio of the paper is available at: doi: 10.4315/0362-028X.JFP-15-335

strengthened with the revised nano-food labeling requirement because of increased transparency and availability of information (56). Labeling of foods containing ENMs may also help build trust among stakeholder groups, which may be key to establishing "social legitimacy” of food nanotechnologies (50). It has also been suggested that labeling of foods containing ENMs may help consumers make trade-off decisions (89), provide information to consumers of benefits of nanotechnologies and ENMs such as improved health or fitness qualities of products (50), and increase knowledge regarding ENMs in society (73).

At the same time, labeling of foods containing ENMs may also cause uncertainty among consumers and trigger potentially unfounded anxieties (73) or create a negative stigma effect for nanotechnologies (50). Because labeling a product containing ENMs may be construed to be a type of warning label (89), some consumers may perceive the labelled food as more risky than a food without a label (89). This may especially be the case if consumers are not familiar with the word "nano" as shown in the list of food ingredients, potentially evoking a negative affect. Because consumers generally have limited awareness of nanotechnologies or ENMs (85), labeling of foods containing ENMs could lead to misunderstanding and fear (89), possibly leading to divestment and technology avoidance in consumer products (50). It has also been argued that labeling of ENMs in foods may potentially exacerbate consumers' already-existing perceptions of ENMs and/or nanotechnology. In this case, labeling could further enhance positive perceptions of nanotechnology in individuals already favoring nanotechnology or could serve as a type of warning symbol for those already with a negative view of nanotechnology, essentially leading to enhanced acceptance or discrimination of products containing ENMs (56). It has also been suggested that labeling could lead to providing consumers with "too much 
This is a post-print version of Grieger et al. (2016). International Implications of Labeling Foods Containing Engineered Nanomaterials. Journal of Food Protection, 79(5), 830-842.

The printed versio of the paper is available at: doi: 10.4315/0362-028X.JFP-15-335

information” that may defeat the original purpose of facilitating improved consumer decisionmaking (i.e., information "overload” which may end up confusing consumers rather than facilitate informed purchase decisions). In fact, some authors have questioned whether the use of mandatory labeling of products containing ENMs actually help consumers make informed decisions since this may not be easy to evaluate (89).

Public perception studies have shown that across nanotechnology-enabled applications, those which were food or health-related are considered more risky compared to others that are not ingested or directly in contact with the body (89). Other studies have shown that public attitudes about nanotechnology in food are more differentiated than in other application categories (87), with more positive attitudes for food applications that involve healthy improvements (e.g. reduced salt, fat content) and more negative attitudes for trivial food applications that involved new flavors or textures $(88,102)$. Because of this, it has been postulated that consumers may respond positively to ENMs in foods because many nano-food applications are related to improving consumer health outcomes. On the other hand, this may be negated by the fact that the use of ENMs in food may not be appealing to consumers, similar to other novel foods $(87,88)$. Another important aspect related to consumer appeal is the concept of "naturalness," whereby some consumers may prefer a more "natural" food than those presented by application of nanotechnology, creating reluctance towards consuming these novel products $(87,88)$. Three main factors seem to shape consumer perceptions of ENMs in food: trust in the food industry, (negative) affect, and control $(87,88)$. This is mirrored in other studies which have shown that consumers are generally skeptical about the effectiveness of public regulation, oversight, and control of nanotechnologies (53). Applications involving foods were ranked among the highest in terms of risk and concern (65). Moreover, in cases of novel technologies, 
This is a post-print version of Grieger et al. (2016). International Implications of Labeling Foods Containing Engineered Nanomaterials. Journal of Food Protection, 79(5), 830-842.

The printed versio of the paper is available at: doi: 10.4315/0362-028X.JFP-15-335

consumers tend to rely on third parties for information, underscoring the lack of trust in regulatory agencies and industry among the public (53).

\section{IMPACTS ON INDUSTRY}

The revised EU requirements on labeling foods containing ENMs will certainly impact food producers, manufacturers, suppliers and others within the food supply chain in the EU as well as in non-EU countries. One potential positive impact may be a better alignment of consumer interests with those of industry, as consumers have more information related to their food purchases. This process may help ensure that industry develops and produces healthy and sustainable food products which appeal to consumers (73). Another positive impact is the improved ability of industry to trace products containing ENMs, with improved mechanisms to ensure food safety. For instance, if there is an outbreak or need to recall a food or food product, improved product traceability will help facilitate product recalls (47). Industry will also have better knowledge of the use of ENMs in their products which will increase their own product information (47). On the other hand, without proper analytical techniques to detect, measure, and characterize ENMs in foods, these potential positive impacts may not be fully realized.

Food industries within and outside the EU will also likely to face a number of challenges related to the implementation of EU Regulation No 1169/2011. Increased costs to food manufacturers and producers may result from revising food labels, some of which could be passed onto customers, at least in the short term while the changes to existing food labels are made (56). More serious obstacles will be faced by industry in terms of detecting, characterizing, and/or quantifying ENMs in food products. Given the current analytical challenges in these fields to robustly validate the presence and concentrations of ENMs in foods, it will be challenging and 
This is a post-print version of Grieger et al. (2016). International Implications of Labeling Foods Containing Engineered Nanomaterials. Journal of Food Protection, 79(5), 830-842.

The printed versio of the paper is available at: doi: 10.4315/0362-028X.JFP-15-335

costly to develop or employ these methods. It has been suggested that given the complexity of detecting ENMs in complex and diverse food matrices, a range of analytical detection and characterization methods may be needed, which may ultimately increase testing costs (56), partially of which is likely to be borne by industry.

An additional challenge faced by industry, particularly in the short term, involves the labeling of nanoscale food additives which have been in use for a long time, such as Synthetic Amorphous Silica (SAS) (E551) which has been used for decades (56). Currently there are on-going discussions in the EU on which substances may be exempt from labeling requirements due to their presence on the EU list of food additives (27). Another challenge likely faced by industry, especially non-EU industries wishing to export to an EU market, relates to the regulatory definition of ENM used for labeling. The EC definition (EC No 2011/696/EU) includes a threshold value ( $\geq 50 \%$ of particles in the range $1-100 \mathrm{~nm}$ ) while the one provided in EU Regulation 1169/2011 does not, although it has been proposed to be revised to include a threshold value. It has been suggested that the establishment of a threshold value may actually benefit industry, since it may be nearly impossible to guarantee a food product to be absent from ENMs in the finished product due to accidental or incidental introduction of ENMs from other processes such as flour grinding (56). While it is expected that upcoming guidance or regulation will further refine the definition of ENMs to be used specifically for EU food labeling requirements, including the use of threshold values, industries may face challenges related to this lack of regulatory clarity in the near term.

Industry, particularly outside the EU, will also likely face additional difficulties and costs related to different information requirements or regulations between countries or regulatory agencies. This could potentially create international trade barriers or disputes, such as issues related to The 
This is a post-print version of Grieger et al. (2016). International Implications of Labeling Foods Containing Engineered Nanomaterials. Journal of Food Protection, 79(5), 830-842.

The printed versio of the paper is available at: doi: 10.4315/0362-028X.JFP-15-335

Transatlantic Trade and Investment Partnership, also impacting manufacturers, distributors, importers, and downstream users (56). In fact, US industries have expressed concerns regarding the lack of uniform implementation regulations related to EU Regulation 1169/2011 (104). US industries have also stated their concerns related to meeting several different labeling requirements, especially those that cannot be fulfilled with the use of stickers or supplemental labels. Rather, they have stressed the need for a harmonized EU food labeling requirements and voluntary national schemes (104).

\section{IMPACTS ON REGULATORY AGENCIES AND FOOD SAFETY AUTHORITIES}

One of the main benefits of labeling foods containing ENMs is to improve product traceability and transparency of ENMs in foods. Similar to benefits to industry in regards to product traceability, regulatory agencies will be able to better respond to product recalls or a potential safety issue if one arose. Furthermore, improving knowledge and transparency in terms of which foods contain ENMs is considered a robust regulatory and governance strategy. At the same time, however, it is expected that a number of challenges will need to be overcome to accurately label foods containing ENMs. First, there is a critical need for a harmonized definition of an “engineered nanomaterial," given the divergent definitions provided by the EC (2011) (16) and included in EU Regulation 1169/2011 and whether threshold values should be included in revised definitions. Second, efforts are needed to harmonize different definitions and related regulations relevant for ENMs in food between countries and/or regulatory agencies, especially if the same material is defined differently by different agencies (56). Some have noted that these harmonization efforts between countries and/or regulatory agencies will help reduce international trade barriers as well as other obstacles that may occur within the international food supply chain $(56,104)$. 
This is a post-print version of Grieger et al. (2016). International Implications of Labeling Foods Containing Engineered Nanomaterials. Journal of Food Protection, 79(5), 830-842.

The printed versio of the paper is available at: doi: 10.4315/0362-028X.JFP-15-335

As discussed by several authors $(56,96,101)$, there are serious challenges to detecting, characterizing, quantifying, and monitoring ENMs in foods due to the lack of suitable analytical techniques and standard practices. These challenges severely hinder the ability to validate the presence or concentrations of ENMs in diverse foods. Detection and characterization methods are still in the development phase, and thus more time is needed in order to develop standard practices within both the scientific and regulatory communities $(56,101)$. Research needs for developing detection and characterization techniques for ENMs in food include: i) the development of benchmark or reference materials to measure a range of nanoscale sizes and other parameters $(82,96)$; ii) the ability to characterize ENMs in the final food product, often more challenging than characterizing pristine or raw $\operatorname{ENMs~}(4,96)$; and iii) the development of standard practices for sample preparation $(4,101)$. While there are on-going activities to address many of these research needs, such as the harmonization of test methods and determination of number-based distribution of ENMs (62, 77), additional research and harmonization efforts are needed within the scientific and regulatory communities to develop standardized practices. Another significant analytical challenge is accounting for interactions between the ENM and other components within the food or food product, which can alter aggregation/agglomeration states, size, shape, and other physicochemical properties of the ENMs needed to ensure accurate labeling of foods containing ENMs $(96,105)$. These aforementioned analytical challenges may be further heightened given the movement from metal-based ENMs to more organic-based ENMs in foods and food products (27), since detecting organic ENMs in food matrices may be particularly difficult. Furthermore, if additional detection and/or characterization tests are needed to account for alterations to the ENM within a food, this may increase the overall costs of detecting and characterizing ENMs in foods. These costs may be borne by industry (and 
This is a post-print version of Grieger et al. (2016). International Implications of Labeling Foods Containing Engineered Nanomaterials. Journal of Food Protection, 79(5), 830-842.

The printed versio of the paper is available at: doi: 10.4315/0362-028X.JFP-15-335

potentially passed on to consumers) as well as regulatory agencies and food safety authorities to ensure accurate labeling of foods and food products.

Further challenges may be faced by food safety authorities outside the EU if foods containing ENMs are required to be labeled in Europe and not elsewhere, leading to an inconsistent trade and labeling systems. It has been suggested that this could possibly lead to international trade disputes, as what was seen in the case of other novel food technologies (37). A lack of international harmonization of food labels could also result in challenges especially for non-EU food safety authorities, such as the US FDA and USDA, whereby different labeling requirements would be needed for different national markets. For example, some nano-scale substances previously recognized as GRAS in the US, such as some food additives, may then require special labels for the EU market. This situation could potentially generate diverse reactions from stakeholder groups, including potential push-back by US industries to prepare special labeling requirements for the EU market, as was seen by requests from the Grocery Manufacturers Association (7). Food safety authorities in the US could also potentially receive criticism from consumer groups, in terms of the rationale for why US regulators are not demanding the same transparency requirements for foods containing ENMs as European regulators, potentially leading to a greater mistrust of US regulatory authorities and their ability to protect consumer interests.

\section{CONCLUSIONS}

The revised EU food labeling requirements (Reg. No 1169/2011) which mandate that foods containing ENMs be labelled will likely result in a number of positive developments as well as a number of challenges for diverse stakeholder groups both in the EU as well as in non-EU countries such as the US. Some of the main positive consequences are likely to be: i) improved 
This is a post-print version of Grieger et al. (2016). International Implications of Labeling Foods Containing Engineered Nanomaterials. Journal of Food Protection, 79(5), 830-842.

The printed versio of the paper is available at: doi: 10.4315/0362-028X.JFP-15-335

transparency and information regarding foods containing ENMs, ii) provision of a proactive response to European consumer concerns regarding the use of ENMs in food, iii) provision of a mechanism for industry to better align with (EU) consumer interests, iv) improved ability to trace products containing ENMs in Europe, and iv) an opportunity for food safety authorities and industry outside the EU to observe the reactions and consequences in the EU following mandatory labeling for foods containing ENMs, which may ultimately translate into better practices to address foods containing ENMs in their own respective countries (i.e., "lessons learned”). At the same time, there will also be a number of significant challenges related to labeling foods containing ENMs for stakeholder groups both inside and outside the EU. These include the need for: i) harmonized information requirements or regulations between countries residing in different regions of the world, ii) clarification on the regulatory definitions of ENMs to be used for food labeling, iii) robust techniques to detect, measure, and characterize diverse ENMs in food matrices, and iv) clarification on the list of ENMs that may be exempt from labeling requirements such as several food additives which have been used for decades. In light of these overall findings, it is recommended that food industries as well as food safety authorities be more proactive in communicating to the public and consumer groups the potential benefits and risks of using ENMs in foods. Past experience with other novel food technologies such as genetically-modified foods in which industry used a "hide, wait, and see” strategy demonstrated the need to be more proactive in public engagement and dialogue when using novel food technologies (53). By not being more proactive, these food industries run the risk of having adverse economic and reputation repercussions as well as potential litigations from not openly discussing the use of these novel materials in food products currently on the consumer 
This is a post-print version of Grieger et al. (2016). International Implications of Labeling Foods Containing Engineered Nanomaterials. Journal of Food Protection, 79(5), 830-842.

The printed versio of the paper is available at: doi: 10.4315/0362-028X.JFP-15-335

market (53). Some have argued that becoming an active player in public dialogues regarding the use of ENMs in food may be an essential strategy to reduce feelings of distrust towards industry. Similarly, non-EU food safety authorities (such as the US FDA and USDA) should be proactive in public dialogues involving the use of ENMs in foods, and when needed, respond to concerns regarding safety and regulatory approval of the ENMs currently on the market. These calls for increased public dialogue and education in terms of the use of ENMs in food have also been recommended by European regulatory food safety experts (25). Another option US food safety authorities could implement in the short term is to mandate reporting and recordkeeping by companies involved in the manufacturing and use of ENMs in foods. This could be similar to what the US Environmental Protection Agency (EPA) has recently proposed under its Toxic Substances Control Act program (29), serving as a potential first step towards better assessing the need for further actions regarding the use of ENMs in food. Finally, it is recommended that food safety authorities both within and outside the EU be proactive to ensure a harmonization of international regulatory requirements and definitions related to the use of ENMs in foods to avoid international trade disputes or challenges. 
This is a post-print version of Grieger et al. (2016). International Implications of Labeling Foods Containing Engineered Nanomaterials. Journal of Food Protection, 79(5), 830-842.

The printed versio of the paper is available at: doi: 10.4315/0362-028X.JFP-15-335

\section{REFERENCES}

1. Auttachoat, W., C.E. McLoughlin, K.L. White, and M.J. Smith. 2014. Route-dependent systemic and local immune effects following exposure to solutions prepared from titanium dioxide nanoparticles. J. Immunotoxicol., 11: 273-282.

2. Birt, D.F., and G.J. Phillips. 2014. Diet, genes, and microbes: complexities of colon cancer prevention. Toxicol. Pathol., 42: 182-188.

3. Bouwmeester, H., S. Dekkers, M.Y. Noordam, W.I. Hagens, A.S. Bulder, C. de Heer, S.E. ten Voorde, S.W. Wijnhoven, H.J. Marvin, and A.J. Sips. 2009. Review of health and safety aspects of nanotechnologies in food production. Reg. Toxicol. Pharmacol., 53(1): 52-62.

4. Bouwmeester, H., P. Brandhoff, H. Marvin, S. Weigel, and R. Peters. 2014. State of the safety assessment and current use of nanomaterials in food and food production. Trends Food Sci Tech, 40: $200-210$.

5. Lomer, M., R. Thompson, J. Powell. 2002. Fine and ultrafine particles of the diet: influence on the mucosal immune response and association with Crohn's disease. Proceed. Nutr. Soc., 61: 123-130.

6. Cedervall, T., I. Lynch, S. Lindman, T. Berggard, E. Thulin, H. Nilsson, K.A. Dawson, and S. Linse. 2007. Understanding the nanoparticle-protein corona using methods to quantify exchange rates and affinities of proteins for nanoparticles. Proceed. Nat. Acad. Sci. United States of Amer., 104: 2050-2055.

7. Center for Food Safety. 2014. Trade Matters: Transatlantic trade and investment partnership (TTIP)-Impacts on Food and Farming. May 2014. Available: http://www.centerforfoodsafety.org/files/trade matters 1014 19123.pdf 
This is a post-print version of Grieger et al. (2016). International Implications of Labeling Foods Containing Engineered Nanomaterials. Journal of Food Protection, 79(5), 830-842.

The printed versio of the paper is available at: doi: 10.4315/0362-028X.JFP-15-335

8. Chaudhry, Q., M. Scotter, J. Blackburn, B. Ross, A. Boxall, L. Castle, R. Aitken, and R. Watkins. 2008. Applications and implications of nanotechnologies for the food sector. Food Addit.

Contam. Part A - Chem. Anal. Control Expo. Risk Assess., 25(3): 241-58.

9. Chen, H., J.N. Seiber, and M. Hotze. 2014. ACS Select on Nanotechnology in Food and Agriculture: A perspective on implications and applications. J. Agr. Food Chem., 62: 1209-1212.

10. Clayton, T.A., D. Baker, J.C. Lindon, J.R. Everett, and J.K. Nicholson. 2009.

Pharmacometabonomic identification of a significant host-microbiome metabolic interaction affecting human drug metabolism. Proceed. Nat. Acad. Sci. United States of Amer., 106:1472814733.

11. Cockburn, A., R. Bradford, N. Buck, A. Constable, G. Edwards, B. Haber, P. Hepburn, J. Howlett, F. Kampers, C. Klein, M. Radomski, H. Stamm, S. Wijnhoven, and T. Wildemann. 2012. Approaches to the safety assessment of engineered nanomaterials (ENM) in food. Food Chem. Toxicol., 50(6): 2224-42.

12. Cox, L.M., and M.J. Blaser. 2013. Pathways in microbe-induced obesity. Cell Metab., 17: 883-894.

13. Dalal, S.R., and E.B. Chang. 2014. The microbial basis of inflammatory bowel diseases. J. Clin. Invest., 124: 4190-4196.

14. Dekkers, S., P. Krystek, R.J. Peters, D.X. Lankveld, B.G. Bokkers, P.H. van Hoeven-Arentzen, H. Bouwmeester, and A.G. Oomen. 2011. Presence and risks of nanosilica in food products. Nanotoxicol., 5: 393-405.

15. Directorate-General for Health and Consumers (DG SANCO). 2013: Commission Delegated Regulation amending Regulation EU 1169/2011 of the European Parliament and Council on the Provision of food information to consumer as regards the definition of "engineered nanomaterials," SANCO 11616/2013. 
This is a post-print version of Grieger et al. (2016). International Implications of Labeling Foods Containing Engineered Nanomaterials. Journal of Food Protection, 79(5), 830-842.

The printed versio of the paper is available at: doi: 10.4315/0362-028X.JFP-15-335

16. European Commission (EC). 2011. Commission Recommendation of 18 October 2011 on the definition of nanomaterial, 2011/696/EU: 38-40, Off. J. Europ. Union, L275: 38-40.

17. EC. 2012. Communication from the Commission to the European Parliament, the Council and the European Economic and Social Committee on the Second Regulatory Review of nanomaterials, including safety aspects. COM(2012) 572 final, SWD(2012) 288 of 3.10.2012. Brussels: European Commission.

18. EC. 2013a. Proposal for a Regulation of the European Parliament and of the Council on novel foods. $\operatorname{COM}(2013) 894$ final.

19. EC. 2013b. Questions and Answers on the Application of the Regulation (EU) No 1169/2011 on the Provision of Food Information to Consumers. 13 January 2013.

20. EC. 2014a. Questions and Answers on Food Information to Consumers. Brussels, 11 December 2014. Available: http://europa.eu/rapid/press-release MEMO-14-2561 en.htm

21. EC. 2014b. Infographic explaining new food labelling rules: New EU Food Labeling Rules from $13^{\text {th }}$ December 2014. Available:

http://ec.europa.eu/food/food/labellingnutrition/foodlabelling/docs/infographic food labelling rules 2014 en.pdf

22. EC. 2014c. Food: EU consumers to benefit from better labelling as of 13 December 2014. Press release. Brussels, 11 December 2014. Available: http://europa.eu/rapid/press-release IP-14$\underline{2560 \text { en.htm }}$

23. European Food Safety Authority (EFSA). 2011a. Scientific Opinion on Guidance on the risk assessment of the application of nanoscience and nanotechnologies in the food and feed chain. EFSA J., 9(5):2140 [36 pp.]. doi:10.2903/j.efsa.2011.2140. Available online: ww.efsa.europa.eu/efsajournal.htm 
This is a post-print version of Grieger et al. (2016). International Implications of Labeling Foods Containing Engineered Nanomaterials. Journal of Food Protection, 79(5), 830-842.

The printed versio of the paper is available at: doi: 10.4315/0362-028X.JFP-15-335

24. EFSA. 2011b. Scientific Opinion on the Safety Evaluation of the Substance, Silver Zeolite A (Silver Zinc Sodium Ammonium Alumino Silicate), Silver Content 2\%-5\%, for Use in Food Contact Materials. EFSA Journal, 9(2): 1999. Available online:

http://www.efsa.europa.eu/en/efsajournal/doc/1999.pdf.

25. EFSA. 2012. Subject: Application of the Definition on nanomaterial to food and feed, Letter from Scientific Committee Unit. Parma, Ref. CGL/DL/RS/op (2012)- out-6833759, 3 October 2012. Available:

http://www.efsa.europa.eu/en/edinterviews/docs/corporatenanotechnology121003.pdf

26. EFSA. 2013. Annual report of the EFSA Scientific Network of Risk Assessment of Nanotechnologies in Food and Feed for 2013. Technical Report. EFSA supporting publication 2013: EN-531. Available: http://www.efsa.europa.eu/en/search/doc/531e.pdf

27. EFSA. 2014. Inventory of Nanotechnology applications in the agricultural, feed and food sector. EFSA supporting publication 2014: EN-621, 125pp.

28. EFSA. 2015. Annual report of the EFSA Scientific Network of Risk Assessment of Nanotechnologies in Food and Feed1 for 2014. Technical Report, EFSA supporting publication 2013: EN-762.

29. Environmental Protection Agency (EPA). 2015. Control of Nanoscale Materials under the Toxic Substances Control Act. United States EPA, April 7, 2015. Available: http://www.epa.gov/oppt/nano/

30. European Parliament. 2009. Nanotechnology in the Food Sector. Science and Technology Options Assessment. December 2009, PE 424.755. Available: https://www.taswiss.ch/?redirect=getfile.php\&cm $\% 5$ Bgetfile $\% 5 \mathrm{D} \% 5$ Buid $\% 5 \mathrm{D}=1665$ 
This is a post-print version of Grieger et al. (2016). International Implications of Labeling Foods Containing Engineered Nanomaterials. Journal of Food Protection, 79(5), 830-842.

The printed versio of the paper is available at: doi: 10.4315/0362-028X.JFP-15-335

31. European Parliament and Council. 1994. European Parliament and Council Directive 94/35/EC of 30 June 1994 on colours for use in foodstuffs. Off. J. Europ. Union, No L 237/13, 13-29. Available: http://ec.europa.eu/food/fs/sfp/addit flavor/flav08 en.pdf

32. European Parliament and Council. 1997. Regulation (EC) No. 258/97 of the European Parliament and of the Council of 27 January 1997 concerning novel foods and novel food ingredients. Official Journal of the European Communities. Off. J. Europ. Union, L43: 1-6.

33. European Parliament and Council. 2002. Directive 2002/46/EC of the European Parliament and of the Council of 10 June 2002 on the approximation of the laws of the Member States relating to food supplements. Off. J. Europ. Union, L183: 7.

34. European Parliament and Council. 2008. Regulation (EC) No 1331/2008 of the European Parliament and of the Council of 16 December 2008 establishing a common authorisation procedure for food additives, food enzymes and food flavourings. Off. J. Europ. Union, L354: 1633.

35. European Parliament and Council. 2011. Regulation (EU) No 1169/2011 of the European Parliament and of the Council of 25 October 2011 on the provision of food information to consumers, amending Regulations (EC) No 1924/2006 and (EC) No 1925/2006 of the European Parliament and of the Council, and repealing Commission Directive 87/250/EEC, Council Directive 90/496/EEC, Commission Directive 1999/10/EC, Directive 2000/13/EC of the European Parliament and of the Council, Commission Directives 2002/67/EC and 2008/5/EC and Commission Regulation (EC) No 608/2004. Off. J. Europ. Union, L304: 18-63.

36. European Parliament News. 2014. Novel foods: MEPs call for moratorium on nano-foods and labeling of cloned meat. Press release, November 25, 2014. Available: http://www.europarl.europa.eu/news/en/news-room/content/20141125IPR80424/html/Novelfoods-MEPs-call-for-moratorium-on-nano-foods-and-labelling-of-cloned-meat 
This is a post-print version of Grieger et al. (2016). International Implications of Labeling Foods Containing Engineered Nanomaterials. Journal of Food Protection, 79(5), 830-842.

The printed versio of the paper is available at: doi: 10.4315/0362-028X.JFP-15-335

37. Falkner, R., L. Breggin, N. Jaspers, J. Pendergrass, and R. Porter. 2009. Consumer labeling of nanomaterials in the EU and US: convergence or divergence? Energy Environ. Res. Govern., EERGP BP 2009/03: 1-12.

38. Food and Drug Administration (FDA). 2002. Federal Food, Drug, and Cosmetic Act; As Amended Through P.L. 107-377, Q:\COMP\FDA\FDA.001, Dec. 19, 2012. Available: http://www.epw.senate.gov/FDA 001.pdf

39. FDA. 2009. Food Additives Permitted for Direct Addition to Food for Human Consumption, Silver Nitrate and Hydrogen Peroxide. 21 CFR Part 172, Federal Register, 74(51): 11476-11478. Available: http://www.fda.gov/ohrms/dockets/98fr/E9-5852.htm

40. FDA. 2011. Draft Guidance for Industry: Considering Whether an FDA-Regulated Product Involves the Application of Nanotechnology. Federal Register, FDA-2010-D-0530. Available: https://www.federalregister.gov/articles/2011/06/14/2011-14643/draft-guidance-for-industryconsidering-whether-an-fda-regulated-product-involves-the-application-of

41. FDA. 2012. Draft Guidance for Industry: Assessing the Effects of Significant Manufacturing Process Changes, Including Emerging Technologies, on the Safety and Regulatory Status of Food Ingredients and Food Contact Substances, including Food Ingredients that are Color Additives. Federal Register, Docket No. FDA-2011-D-0490. Available: https://www.federalregister.gov/articles/2012/04/25/2012-9936/draft-guidance-for-industryassessing-the-effects-of-significant-manufacturing-process-changes

42. FDA. 2014a. FDA News Release: FDA issues Guidance to Support the Responsible Development of Nanotechnology Products. June 2014, 2014. Available: http://www.fda.gov/NewsEvents/Newsroom/PressAnnouncements/ucm402499.htm

43. FDA. 2014b. Guidance for Industry: Assessing the Effects of Significant Manufacturing Process Changes, Including Emerging Technologies, on the Safety and Regulatory Status of Food 
This is a post-print version of Grieger et al. (2016). International Implications of Labeling Foods Containing Engineered Nanomaterials. Journal of Food Protection, 79(5), 830-842.

The printed versio of the paper is available at: doi: 10.4315/0362-028X.JFP-15-335

Ingredients and Food Contact Substances, Including Food Ingredients that Are Color Additives.

Federal Register, Docket Number FDA-2011-D-0490. Available:

http://www.fda.gov/Food/GuidanceRegulation/GuidanceDocumentsRegulatorylnformation/Ing redientsAdditivesGRASPackaging/ucm300661.htm

44. FDA. 2014c. Guidance for Industry: Considering Whether an FDA-Regulated Product Involves the Application of Nanotechnology. Federal Register, 79 FR 36534. Available: http://www.fda.gov/RegulatoryInformation/Guidances/ucm257698.htm

45. Fontana, L., V. Leso, A. Marinaccio, G. Cenacchi, V. Papa, K. Leopold, R. Schindl, B. Bocca, A. Alimonti, and I. lavicoli. 2014. The effects of palladium nanoparticles on the renal function of female Wistar rats. Nanotoxicol., DOI: 10.3109/17435390.2014.980759.

46. Friends of the Earth (FOE). 2014 - Way too little: Our Government's Failure to Regulation Nanomaterials in Food and Agriculture. Friends of the Earth Australia, May 2014.

47. German Federal Environment Agency. 2014. Assessment of Impacts of a European Register of Products Containing Nanomaterials. Project No. (FKZ) 36001 072, Report No. (UBA-FB) 001907/E. October 2013.

48. Grieger, K., C. Sayes, C.O. Hendren, G. Rothrock, C. Mansfield, R.K.M. Jayanty, and D. Ensor. 2013. Multi-stakeholder collaboration is key to solving society's grand challenges: The case of responsible nanomaterial development. EHS Today, December Issue; Available: http://ehstoday.com/training/finding-key-responsible-nanomaterial-development?page=1.

49. Grieger, K., S.F. Hansen, and A. Baun. 2009. The known unknowns of nanomaterials: Describing and characterizing uncertainty within environmental, health and safety risks. Nanotoxicol., 3(3): $1-12$.

50. Gruere, G.P. 2011. Labeling nano-enabled consumer products. Nano Today, 6: 117-121. 
This is a post-print version of Grieger et al. (2016). International Implications of Labeling Foods Containing Engineered Nanomaterials. Journal of Food Protection, 79(5), 830-842.

The printed versio of the paper is available at: doi: 10.4315/0362-028X.JFP-15-335

51. International Organization for Standardization (ISO). 2013. Nanotechnologies- Guidance on voluntary labelling for consumer products containing manufactured nano-objects. ISO/TS 13830:2013(en).

52. ISO. 2014. Nanotechnologies - Considerations for the development of chemical nomenclature for selected nano-objects. ISO/TR 14786:2014(en), Available: https://www.iso.org/obp/ui/\#iso:std:iso:tr:14786:ed-1:v1:en

53. International Risk Governance Council (IRGC). 2008. Risk Governance of Nanotechnology Applications in Food and Cosmetics. Geneva, September 2008.

54. Ivy Rose Holistic. 2008. E172. Available: http://www.ivyroses.com/Define/E172

55. Jo, E., G. Seo, J.T. Kwon, M. Lee, B.C. Lee, I. Eom, and K. Choi. 2013. Exposure to zinc oxide nanoparticles affects reproductive development and biodistribution in offspring rats. J. Toxicol. Sci., 38:6.

56. Joint Research Centre (JRC). 2014a. Considerations on Information Needs for Nanomaterials in Consumer Products: Discussion of a Labelling and Reporting Scheme for Nanomaterials in Consumer Products in the EU. JRC Scientific and Policy Reports, European Commission, April 2014.

57. JRC. 2014b. Towards a review of the EC Recommendation for a definition of the term "nanomaterial," Part 1: Compilation of information concerning the experience with the definition. JRC Scientific and Policy Reports, European Commission, March 2014.

58. Kau, A.L., P.P. Ahern, N.W. Griffin, A.L. Goodman, and J.I. Gordon. 2011. Human Nutrition, the gut microbiome and the immune system. Nature, 474: 327-336. DOI: 10.1038/nature10213.

59. Kim, Y.S., J.S. Kim, H.S. Cho, D.S. Rha, J.M. Kim, J.D. Park, B.S. Choi, R. Lim, H.K. Chang, Y.H. Chung, I.H. Kwon, J. Jeong, B.S. Han, and I.J. Yu. 2008. Twenty-eight-day oral toxicity, 
This is a post-print version of Grieger et al. (2016). International Implications of Labeling Foods Containing Engineered Nanomaterials. Journal of Food Protection, 79(5), 830-842.

The printed versio of the paper is available at: doi: 10.4315/0362-028X.JFP-15-335

genotoxicity, and gender-related tissue distribution of silver nanoparticles in Sprague-Dawley rats. Inhal. Toxicol., 20: 575-583.

60. Lee, J.H., Y.S. Kim, K.S. Song, H.R. Ryu, J.H. Sung, J.D. Park, H.M. Park, N.W. Song, B.S. Shin, D. Marshak, K. Ahn, J.E. Lee, and I.J. Yu. 2013. Biopersistence of silver nanoparticles in tissues from Sprague-Dawley rats. Part. Fibre Toxicol., 10: 36-49.

61. Lerner, A., and T. Matthias. 2015. Changes in intestinal tight junction permeability associated with industrial food additives explain the rising incidence of autoimmune disease. Autoimmun. Rev., 14: 479-489.

62. Linsinger, T.P.J., G. Roebben, D. Gilliland, L. Calzolai, F. Rossi, N. Gibson, and C. Klein. 2012. Requirements on measurements for the implementation of the European Commission definition of the term "nanomaterial".European Commission Joint Research Centre, Luxembourg . Available: http://publications.jrc.ec.europa.eu/repository/bitstream/111111111/26399/2/irmm nanomat erials\%20\%28online\%29.pdf

63. Lomer, M.C.E., R.P.H. Thompson, J.J. Powell. 2007. Fine and ultrafine particles of the diet: influence on the mucosal immune response and association with Crohn's disease. Proceed. Nutrit. Soc. 61: 123-130.

64. Lundqvist, M., J. Stigler, G. Elia, I. Lynch, T. Cedervall, and K.A. Dawson. 2008. Nanoparticle size and surface properties determine the protein corona with possible implications for biological impacts. Proceed. Nat. Acad. Sci. United States of Amer., 105: 14265-14270.

65. Macoubrie, J. 2005. Informed Public Perception on Nanotechnology and Trust in Government, Project on Emerging Nanotechnologies, Woodrow Wilson International Center for Scholars, New York. Available: 
This is a post-print version of Grieger et al. (2016). International Implications of Labeling Foods Containing Engineered Nanomaterials. Journal of Food Protection, 79(5), 830-842.

The printed versio of the paper is available at: doi: 10.4315/0362-028X.JFP-15-335

http://www.nanotechproject.org/process/files/2709/8 informed public perceptions of nanot echnology and trust in government.pdf

66. Magnuson, B., T. Jonaitis, and J. Card. 2011. A brief review of the occurrence, use, and safety of food-related nanomaterials. J. Food Sci., 76(6): 126-133.

67. Martirosyan, A., Y.J. Schneider. 2014. Engineered nanomaterials in food: implications for food safety and consumer health. Intern. J. Environ. Res. Pub. Health, 11(6): 5720-50.

68. Melnik, E.A., Y.P. Buzulukov, V.F. Demin, V.A. Demin, I.V. Gmoshinski, N.V. Tyshko, and V.A. Tutelyan. 2013. Transfer of silver nanoparticles through the placenta and breast milk during in vivo experiments on rats. Acta Naturae, 5: 107-115.

69. Miyamoto, Y., M. Kajita, and N. Toshima. 2006. Platinum nanocolloid solution, process for producing the same and drink containing platinum nanocolloid. Publication number US 20060024382 A1, Patent application number US 10/539,585. Available: http://www.google.com/patents/US20060024382

70. Montiel-Castro, A.J., R.M. Gonzalez-Cervantes, G. Bravo-Ruiseco, and G. Pacheco-Lopez. 2013. The microbiota-gut-brain axis: N correlates, health and sociality. Front. Integrat. Neurosci., 7: 70.

71. Morris, V.J. 2011. Emerging roles of engineered nanomaterials in the food industry. Trends in Biotechnol., 29(10): 509-517.

72. Mortensen, N.P., G.B. Hurst, W. Wang, C.M. Foster, P.D. Nallathamby, and S.T. Retterer. 2013. Dynamic development of the protein corona on silica nanoparticles: composition and role in toxicity. Nanoscale 5: 6372-6380.

73. Nanowerk. 2012. On voluntary and obligatory nanotechnology labeling. Michael Berger (Ed), September 17, 2012. Available: http://www.nanowerk.com/spotlight/spotid=26725.php

74. National Institute for Occupational Safety and Health (NIOSH). 2013. Protecting the Nanotechnology Workforce: NIOSH Nanotechnology Research and Guidance Strategic Plan, 
This is a post-print version of Grieger et al. (2016). International Implications of Labeling Foods Containing Engineered Nanomaterials. Journal of Food Protection, 79(5), 830-842.

The printed versio of the paper is available at: doi: 10.4315/0362-028X.JFP-15-335

2013-2016. Department Of Health and Human Services, Centers for Disease Control and Prevention, Publication No. 2014-106.

75. National Nanotechnology Initiative (NNI). 2014. National Nanotechnology Initiative Strategy Plan. National Science and Technology Council, Committee on Technology, Subcommittee on Nanoscale Science, Engineering, and Technology February 2014. Available: http://www.nano.gov/node/1113.

76. Oberdorster, G., E. Oberdorster, and J. Oberdorster. 2005. Nanotoxicology: An emerging discipline evolving from studies of ultrafine particles. Environ. Health Perspect., 113(7): 823-839.

77. Organisation for Economic Co-operation and Development (OECD). 2012. Guidance on Sample Preparation and Dosimetry for the Safety Testing of Manufactured Nanomaterials. Series on the Safety of Manufactured Nanomaterials, No. 36. ENV/JM/MONO(2012)40.

78. Park, E.J., E. Bae, J. Yi, Y. Kim, K. Choi, S.H. Lee, J. Yoon, B.C. Lee, K. Park. 2010. Repeated-dose toxicity and inflammatory responses in mice by oral administration of silver nanoparticles. Environmental Toxicol. Pharmacol., 30: 162-168.

79. Powell, J.J., R.S. Harvey, P. Ashwood, R. Wolstencroft, M.E. Gershwin, and R.P. Thompson. 2000. Immune potentiation of ultrafine dietary particles in normal subjects and patients with inflammatory bowel disease. J. Autoimmun. 14: 99-105.

80. Project on Emerging Nanotechnologies. 2015. Consumer Products Inventory: An inventory of nanotechnology-based consumer products introduced on the market. Woodrow Wilson International Center for Scholars. Available: http://www.nanotechproject.org/cpi/, Accessed January 25, 2015.

81. Qin, J., R. Li, J. Raes, M. Arumugam, K.S. Burgdorf, C. Manichanh, T. Nielsen, N. Pons, F. Levenez, T. Yamada, D.R. Mende, J. Li, J. Xu, S. Li, D. Li, J. Cao, B. Wang, H. Liang, H. Zheng, Y. Xie, J. Tap, P. Lepage, M Bertalan, J.M. Batto, T. Hansen, D. Le Paslier, A. Linneberg, H.B. Nielsen, E. Pelletier, 
This is a post-print version of Grieger et al. (2016). International Implications of Labeling Foods Containing Engineered Nanomaterials. Journal of Food Protection, 79(5), 830-842.

The printed versio of the paper is available at: doi: 10.4315/0362-028X.JFP-15-335

P. Renault, T. Sicheritz-Ponten, K. Turner, H. Zhu, C. Yu, S. Li, M. Jian, Y. Zhou, Y. Li, X. Zhang, S.

Li, N. Qin, H. Yang, J. Wang, S. Brunak, J. Dore, F. Guarner, K. Kristiansen, O. Pedersen, J. Parkhill, J. Weissenbach, H. Meta, P. Bork, S.D. Ehrlich, and J. Wang. 2010. A human gut microbial gene catalogue established by metagenomic sequencing. Nature, 464: 59-65.

82. Roebben, G., K. Rasmussen, V. Kestens, T.P.J. Linsinger, H. Rauscher, H. Emons, and H. Stamm. 2013. Reference materials and representative test materials: The nanotechnology case. J. Nanopart. Res., 15: 1455 -1468.

83. Saad, R., M.R. Rizkallah, and R.K. Aziz. 2012. Gut Pharmacomicrobiomics: The tip of an iceberg of complex interactions between drugs and gut-associated microbes. Gut Path., 4:1-13.

84. Sandler, R., and W. Kay. 2006. The GMO-Nanotech (Dis)Analogy? Bull. Sci., Technol. Soc., 26(1): $57-62$.

85. Satterfield, T., M. Kandlikar, C.E. Beaudrie, J. Conti, and B. Harthorn. 2009. Anticipating the perceived risk of nanotechnologies. Nature Nanotechnol., 4:752-758.

86. Scientific Committee on Emerging and Newly Identified Health Risks (SCENIHR). 2014. Nanosilver: safety, health and environmental effects and role in antimicrobial resistance. European Commission, 10.2772/76851.

87. Siegrist, M., M.E. Cousin, H. Kastenholz, and A. Wiek. 2007. Public acceptance of nanotechnology foods and food packaging: The influence of affect and trust. App., 49: 459-466.

88. Siegrist, M., N. Stampfli, H. Kastenholz, and C. Keller. 2008. Perceived risks and perceived benefits of different nanotechnology foods and nanotechnology food packaging. App., 51:283290.

89. Siegrist, M., and C. Keller. 2011. Labeling of Nanotechnology Consumer Products Can Influence Risk and Benefit Perceptions. Risk Anal., 31(11): 1762-1769.

90. Sjöberg, L. 2000. Perceived risk and tempering with nature. J. Nanopart. Res., 3(4): 353-367. 
This is a post-print version of Grieger et al. (2016). International Implications of Labeling Foods Containing Engineered Nanomaterials. Journal of Food Protection, 79(5), 830-842.

The printed versio of the paper is available at: doi: 10.4315/0362-028X.JFP-15-335

91. Snyder, R.W., T.R. Fennell, C.J. Wingard, N.P. Mortensen, N.A. Holland, J.H. Shannahan, W. Pathmasiri, A.H. Lewin, and S.C.J. Sumner. 2015. Distribution and biomarker of carbon-14 labeled fullerene $c 60([14 c(u)] c 60)$ in pregnant and lactating rats and their offspring after maternal intravenous exposure. J. Appl. Toxicol., DOI: 10.1002/jat.3177.

92. Soil Association. 2008. Nanotechnologies and Food Evidence to House of Lords Science and Technology Select Committee. United Kingdom, ST/NF/36. Available: http://www.parliament.uk/documents/lords-committees/sciencetechnology/st136soilassociation.pdf

93. Stamm, H., N. Gibson, A. Anklam. 2012. Detection of nanomaterials in food and consumer products: bridging the gap from legislation to enforcement. Food Add. Contamin., 29(8): 11751182.

94. Supplements Direct. 2014. Cyborg Sport Creapure Creatine - 300g. Available: http://www.supplementsdirect.com.au/cyborg-sport-creapure-creatine-300g

95. Surana, N.K., and D.L. Kasper. 2014. Deciphering the tete-a-tete between the microbiota and the immune system. J. Clin. Invest., 124: 4197-4203.

96. Szakal, C., S. Roberts, P. Westerhoff, A. Bartholomaeus, N. Buck, I. Illuminato, R. Canaday, and M. Rogers. 2014. Measurement of nanomaterials in foods: integrative consideration of challenges and future prospects. ACS Nano, 8(4): 3128-3135.

97. Takenaka, S., E. Karg, C. Roth, H. Schulz, A. Ziesenis, U. Heinzmann, P. Schramel, and J. Heyder. 2001. Pulmonary and systemic distribution of inhaled ultrafine silver particles in rats. Environ. Health Perspect. 109:5.

98. The Nanodatabase. 2015. Available: http://nanodb.dk

99. Theriot, C.M., and V.B. Young. 2014. Microbial and metabolic interactions between the gastrointestinal tract and Clostridium difficile infection. Gut Microbes, 5: 86-95. 
This is a post-print version of Grieger et al. (2016). International Implications of Labeling Foods Containing Engineered Nanomaterials. Journal of Food Protection, 79(5), 830-842.

The printed versio of the paper is available at: doi: 10.4315/0362-028X.JFP-15-335

100. Thompson, L.C., R.N. Urankar, N.A. Holland, A.K. Vidanapathirana, J.E. Pitzer, L. Han, S.J. Sumner, A.H. Lewin, T.R. Fennell, R.M. Lust, J.M. Brown, and C.J. Wingard. 2014. C60 exposure augments cardiac ischemia/reperfusion injury and coronary artery contraction in sprague dawley rats. Toxicol. Sci., 138: 365-378.

101. Tiede, K., A.B. Boxall, S.P. Tear, J. Lewis, and M. Hassellov. 2008. Detection and characterization of engineered nanoparticles in food and the environment. Food Add. Contamin., 25(7): 795-821.

102. United Kingdom Food Standards Agency (UK FSA). 2011. FSA Citizen Forums: Nanotechnology and food. TNS-BMRB Report, JN 219186, April 2011.

103. United States Department of Agriculture (USDA). 2015. Policy Memorandum: Nanotechnology. March 24, 2015. Available: http://www.ams.usda.gov/AMSv1.0/getfile?dDocName=STELPRDC5110949

104. United States Trade Representative (USTR). 2014. 2014 Report on Technical Barriers to Trade. April 2014. Available: https://ustr.gov/sites/default/files/2014\%20TBT\%20Report.pdf

105. von der Kammer, F., P.L. Ferguson, P.A. Holden, A. Masion, K.R. Rogers, S.J. Klaine, A.A. Koelmans, N. Horne, and J.M. Unrine. 2012. Analysis of engineered nanomaterials in complex matrices (environment and biota): General considerations and conceptual case studies. Environ. Toxicol. Chem., 31(1): 32-49.

106. Wang, Z., G. Qu, L. Su, L. Wang, Z. Yang, J. Jiang, S. Liu, and G. Jiang. 2013. Evaluation of the biological fate and the transport through biological barriers of nanosilver in mice. Current Pharmaceut. Des., 19: 6691-6697.

107. Weir, A., P. Westerhoff, L. Fabricius, K. Hristovski, and N. von Goetz. 2012. Titanium dioxide nanoparticles in food and personal care products. Environ. Sci. Technol., 46: 2242-2250. 
This is a post-print version of Grieger et al. (2016). International Implications of Labeling Foods Containing Engineered Nanomaterials. Journal of Food Protection, 79(5), 830-842.

The printed versio of the paper is available at: doi: 10.4315/0362-028X.JFP-15-335

\section{Figure legends}

Figure 1. Fate and Transformation of Ingested ENMs in Food and Potential Health Impacts. 
This is a post-print version of Grieger et al. (2016). International Implications of Labeling Foods Containing Engineered Nanomaterials. Journal of Food Protection, 79(5), 830-842.

The printed versio of the paper is available at: doi: 10.4315/0362-028X.JFP-15-335

\section{Tables}

Table 1. Examples of ENM food applications currently available. This list is not exhaustive of all ENMs in foods and food products but rather aims to provide a snapshot of some ENM-food applications available for consumer purchase. ENM = engineered nanomaterial

\begin{tabular}{|c|c|c|c|c|}
\hline ENM & Commercial Use & Function & $\begin{array}{l}\text { Use in Foods and Food } \\
\text { Products }\end{array}$ & Source \\
\hline $\begin{array}{l}\text { Synthetic } \\
\text { amorphous silica } \\
\text { (SAS, E551) }\end{array}$ & $\begin{array}{l}\text { Evonik’s Aerosil 200F, Aerosil } \\
\text { 380F; used as anti-caking agents } \\
\text { in powdered food items }\end{array}$ & $\begin{array}{l}\text { Added to foods in powder } \\
\text { form to improve their flow }\end{array}$ & $\begin{array}{l}\text { Powders, e.g. salt, whey powder, } \\
\text { egg powder, creamer, instant drinks, } \\
\text { seasoning blends, powdered sugar, } \\
\text { soup powder }\end{array}$ & $\begin{array}{l}\text { Dekkers et al. } \\
\text { 2011; EFSA } 2014\end{array}$ \\
\hline $\begin{array}{l}\text { Titanium dioxide } \\
\text { (E171) }\end{array}$ & $\begin{array}{l}\text { E171 as used in various products, } \\
\text { e.g. Hostess Powdered Donette, } \\
\text { Kool Aid Blue Raspberry, M\&Ms } \\
\text { Chocolate Candy, Trident White } \\
\text { Peppermint Gum, Kraft Mayo, } \\
\text { Kraft Velveeta }\end{array}$ & $\begin{array}{l}\text { Added to foods to bleach or } \\
\text { brighten colors, and/or to } \\
\text { enhance flavor in non-white } \\
\text { foods }\end{array}$ & $\begin{array}{l}\text { Confectionary (e.g. candies, } \\
\text { chewing gum, chocolate), cheese, } \\
\text { sauces, bakery items (e.g. } \\
\text { doughnuts), produce (e.g. pears, } \\
\text { apples, bell peppers) from edible } \\
\text { food coatings }\end{array}$ & $\begin{array}{l}\text { Weir et al. 2012; } \\
\text { EFSA 2014; FOE } \\
2014\end{array}$ \\
\hline
\end{tabular}


This is a post-print version of Grieger et al. (2016). International Implications of Labeling Foods Containing Engineered Nanomaterials. Journal of Food Protection, 79(5), 830-842.

The printed versio of the paper is available at: doi: 10.4315/0362-028X.JFP-15-335

\begin{tabular}{|c|c|c|c|c|}
\hline ENM & Commercial Use & Function & $\begin{array}{l}\text { Use in Foods and Food } \\
\text { Products }\end{array}$ & Source \\
\hline Nano-silver & $\begin{array}{l}\text { American Biotech Lab’s ASAP } \\
\text { Health Max 30; Fair vital’s } \\
\text { Colloidal Silver; La Posta del } \\
\text { Aguila's Maternal Water }\end{array}$ & $\begin{array}{l}\text { Supplement to support } \\
\text { immune system; Nano } \\
\text { colloidal silver ion }\end{array}$ & $\begin{array}{l}\text { Vitamins and dietary supplements; } \\
\text { Added to water as substitution for } \\
\text { chemical water treatment }\end{array}$ & $\begin{array}{l}\text { Project on } \\
\text { Emerging } \\
\text { Nanotechnologies } \\
\text { 2015; The } \\
\text { Nanodatabase } 2015\end{array}$ \\
\hline $\begin{array}{l}\text { Nanoscale iron } \\
\text { oxide (E172) }\end{array}$ & Food additive & $\begin{array}{l}\text { Added as food colorant; } \\
\text { potential iron fortifier }\end{array}$ & $\begin{array}{l}\text { Used in salmon-, shrimp-, and meat } \\
\text { pastes; cake and dessert packets; } \\
\text { soups }\end{array}$ & $\begin{array}{l}\text { Ivy Rose Holistic } \\
\text { 2008; EFSA } 2014\end{array}$ \\
\hline $\begin{array}{l}\text { Nanocolloidal } \\
\text { platinum }\end{array}$ & Patent by Miyamoto et al. 2006 & $\begin{array}{l}\text { Added to foods and } \\
\text { marketed as "anti-aging" } \\
\text { foods }\end{array}$ & Yoghurt, drinks & $\begin{array}{l}\text { Miyamoto et al. } \\
\text { 2006; FOE } 2014\end{array}$ \\
\hline Nanocolloidal gold & Purest Colloids, Inc.’s MesoGold & $\begin{array}{l}\text { Added to foods and } \\
\text { marketed as "anti-aging" } \\
\text { foods }\end{array}$ & Beverages & $\begin{array}{l}\text { FOE 2014; Project } \\
\text { on Emerging } \\
\text { Nanotechnologies } \\
2015\end{array}$ \\
\hline Nano-copper & $\begin{array}{l}\text { Purest Colloids, Inc.’s } \\
\text { MesoCopper }\end{array}$ & $\begin{array}{l}\text { Supplemental form of } \\
\text { copper in deionized water }\end{array}$ & Beverages & $\begin{array}{l}\text { Project on } \\
\text { Emerging }\end{array}$ \\
\hline
\end{tabular}


This is a post-print version of Grieger et al. (2016). International Implications of Labeling Foods Containing Engineered Nanomaterials. Journal of Food Protection, 79(5), 830-842.

The printed versio of the paper is available at: doi: 10.4315/0362-028X.JFP-15-335

\begin{tabular}{|c|c|c|c|c|}
\hline ENM & Commercial Use & Function & $\begin{array}{l}\text { Use in Foods and Food } \\
\text { Products }\end{array}$ & Source \\
\hline & & & & $\begin{array}{l}\text { Nanotechnologies } \\
2015\end{array}$ \\
\hline Nano-selenium & $\begin{array}{l}\text { Shenzhen Become Industry \& } \\
\text { Trade Co., Ltd's Nanotea }\end{array}$ & $\begin{array}{l}\text { Added to improve health } \\
\text { and nutrition: absorb } \\
\text { viruses, free radicals, } \\
\text { cholesterol and blood fat }\end{array}$ & Beverages (tea) & $\begin{array}{l}\text { Project on } \\
\text { Emerging } \\
\text { Nanotechnologies } \\
2015\end{array}$ \\
\hline Nano-calcium & $\begin{array}{l}\text { Good State - Liquid Ionic } \\
\text { Minerals Calcium; Good State - } \\
\text { Liquid Ionic Calcium Ultra } \\
\text { Concentrate; Silvia Osteo Plus } \\
\text { Tablets for stronger bones }\end{array}$ & $\begin{array}{l}\text { Added to food supplements } \\
\text { to improve bone strength via } \\
\text { calcium intake }\end{array}$ & Vitamins and dietary supplements & $\begin{array}{l}\text { The Nanodatabase } \\
2015\end{array}$ \\
\hline $\begin{array}{l}\text { Carotenoids, e.g. } \\
\text { lycopene }\end{array}$ & $\begin{array}{l}\text { Allied Biotech Corporation The } \\
\text { Carotenoid Company, } \\
\text { “Altratene”; BASF’s beta- } \\
\text { carotene for drinks with Lucarotin } \\
10 \text { CWD O and lycopene for food } \\
\text { supplements with LycoVit 10\% }\end{array}$ & $\begin{array}{l}\text { Added as colorants or } \\
\text { antioxidants in foods or } \\
\text { drinks }\end{array}$ & $\begin{array}{l}\text { Various foods, including milk } \\
\text { products, fats and oils, candy, } \\
\text { bottled water, breakfast cereals, } \\
\text { soups, sauces, juices, and baked } \\
\text { goods }\end{array}$ & $\begin{array}{l}\text { European } \\
\text { Parliament } 2009\end{array}$ \\
\hline
\end{tabular}


This is a post-print version of Grieger et al. (2016). International Implications of Labeling Foods Containing Engineered Nanomaterials. Journal of Food Protection, 79(5), 830-842.

The printed versio of the paper is available at: doi: 10.4315/0362-028X.JFP-15-335

\begin{tabular}{|c|c|c|c|c|}
\hline ENM & Commercial Use & Function & $\begin{array}{l}\text { Use in Foods and Food } \\
\text { Products }\end{array}$ & Source \\
\hline & $\begin{array}{l}\text { DC; Chr Hansen solutions of } \\
\text { beta-carotene; } \\
\text { Cognis Group Nutrition \& Health } \\
\text { carotenoid additives in 'Betatene' } \\
\text { product }\end{array}$ & & & \\
\hline $\begin{array}{l}\text { "Nanodrops" } \\
\text { described as } \\
\text { "minute compressed } \\
\text { micelles" }\end{array}$ & $\begin{array}{l}\text { Shemen Industries Canola Active } \\
\text { Oil }\end{array}$ & $\begin{array}{l}\text { Added to reduce cholesterol } \\
\text { levels and improve delivery } \\
\text { of nutrients }\end{array}$ & Canola oil & $\begin{array}{l}\text { Project on } \\
\text { Emerging } \\
\text { Nanotechnologies } \\
2015\end{array}$ \\
\hline $\begin{array}{l}\text { Nano-ceuticals, e.g. } \\
\text { nano-sized powder } \\
\text { with nutrients }\end{array}$ & $\begin{array}{l}\text { RBC’s NanoCluster delivery } \\
\text { system }\end{array}$ & $\begin{array}{l}\text { Added to increase delivery } \\
\text { and absorption of nutrients }\end{array}$ & Chocolate shake & $\begin{array}{l}\text { Project on } \\
\text { Emerging } \\
\text { Nanotechnologies } \\
2015\end{array}$ \\
\hline Nano-encapsulate & NutraLease $^{\mathrm{TM}}$ & $\begin{array}{l}\text { Self-assembled lipid } \\
\text { structures made of micelles; } \\
\text { nano-sized vehicles } \\
\text { containing nutrients }\end{array}$ & Dietary supplement & $\begin{array}{l}\text { Project on } \\
\text { Emerging } \\
\text { Nanotechnologies } \\
2015\end{array}$ \\
\hline
\end{tabular}


This is a post-print version of Grieger et al. (2016). International Implications of Labeling Foods Containing Engineered Nanomaterials. Journal of Food Protection, 79(5), 830-842.

The printed versio of the paper is available at: doi: 10.4315/0362-028X.JFP-15-335

\begin{tabular}{|c|c|c|c|c|}
\hline ENM & Commercial Use & Function & $\begin{array}{l}\text { Use in Foods and Food } \\
\text { Products }\end{array}$ & Source \\
\hline $\begin{array}{l}\text { Various nano- } \\
\text { vitamin } \\
\text { supplements, e.g. } \\
\text { nano peptides, nano } \\
\text { creatine, nanobolics, } \\
\text { nano tribestanol, } \\
\text { nano glutamine }\end{array}$ & $\begin{array}{l}\text { BASF's microcapsulated } \\
\text { vitamins; Supplement Direct’s } \\
\text { nanovitamins }\end{array}$ & Vitamins in nano-form & Vitamins and dietary supplements & $\begin{array}{l}\text { FOE 2014; } \\
\text { Supplements Direct } \\
2014\end{array}$ \\
\hline "Nano-spheres" & $\begin{array}{l}\text { Life Enhancement’s Bionic Joint } \\
\text { Support; LivOn Labs’ Lypo- } \\
\text { Spheric Vitamin C }\end{array}$ & $\begin{array}{l}\text { Supplement to support joint } \\
\text { functioning, improve } \\
\text { bioavailability of hyaluronic } \\
\text { acid; Supplement to } \\
\text { enhance bioavailability and } \\
\text { delivery of Vitamin C }\end{array}$ & Vitamins and dietary supplements & $\begin{array}{l}\text { Project on } \\
\text { Emerging } \\
\text { Nanotechnologies } \\
2015\end{array}$ \\
\hline
\end{tabular}


This is a post-print version of Grieger et al. (2016). International Implications of Labeling Foods Containing Engineered Nanomaterials. Journal of Food Protection, 79(5), 830-842.

The printed versio of the paper is available at: doi: 10.4315/0362-028X.JFP-15-335

\section{Figures}

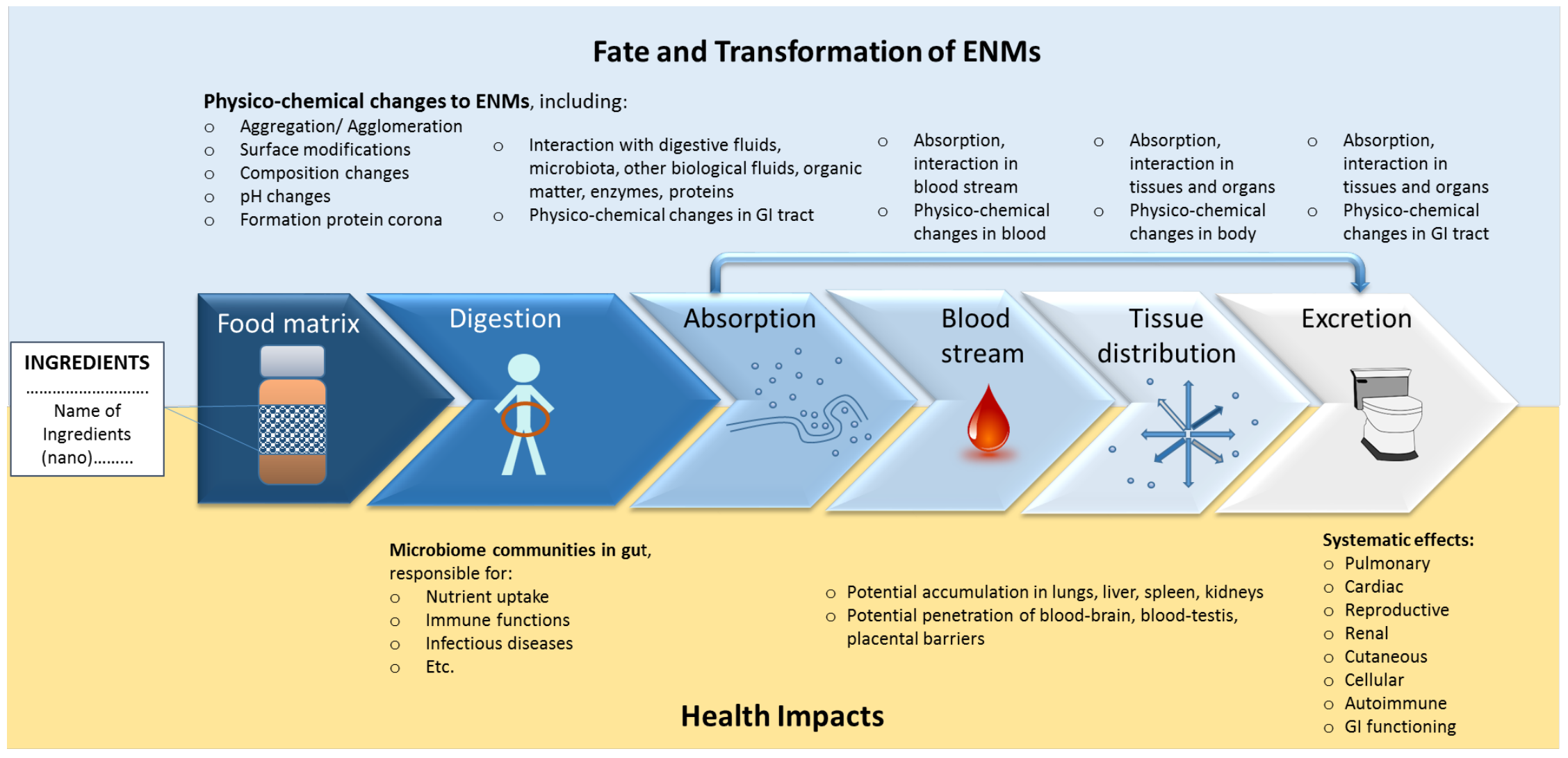

